\title{
Relationship between DOC photochemistry and mercury redox transformations in temperate lakes and wetlands
}

\author{
Edenise Garcia, Marc Amyot, Parisa A. Ariya
}

\begin{abstract}
We compared diurnal variations in dissolved gaseous mercury (DGM) concentration and in losses of dissolved organic carbon fluorescence (DOCF) in four boreal Canadian Shield lakes, in one beaver pond, and in filtered and unfiltered water from a wetland in Lake St. Pierre, a fluvial lake of the St. Lawrence River. These systems were chosen to represent a spectrum of DOC. We also determined the contribution of UVB, UVA and visible light on DGM photo-induced production in the four lakes. Our results showed a strong relationship between DGM concentrations and light intensity and between DGM production and losses in DOCF, in all study sites. We also observed higher rates of DGM formation and of DOCF bleaching in the presence of UV radiation. Under UVB light, production of DGM was higher in clear lakes than in the humic ones. Inversely, in the UVA range, DGM production tended to be higher in humic lakes. We suggest that DOCF bleaching can be used as a proxy for the rate of formation of reactive species that may alter the redox state of mercury in surface waters. We also have indications that DGM production is more important in clear than in humic waters.
\end{abstract}

\section{Introduction}

Diurnal variations in concentration of dissolved gaseous mercury (DGM) are known to occur in surface waters (Amyot et al., 2001; Zhang and Lindberg, 2002; O’Driscoll et al., 2003). Depending on the intensity of solar radiation, wind speed and optical properties of the water column, these variations can be the result of DGM production, evasion or oxidation. In aquatic systems, $\mathrm{Hg}$ speciation is altered by the presence of DOC (dissolved organic carbon), which tends to complex $\mathrm{Hg}(\mathrm{II})$ and to affect light penetration. The absorption of light by chromophoric DOC (CDOC), particularly in the UV range, initiates a variety of important processes in surface waters, including the complete mineralization of DOC to $\mathrm{CO}_{2}$ (Graneli et al., 1996), the production of low molecular weight organic compounds (Lindell et al., 2000) and the formation of photoreactive intermediates that may alter the redox state of $\mathrm{Hg}$ (Bertilsson and Tranvik, 2000). The photochemical reactions that produce these intermediates and products are often accompanied by changes in the optical properties of DOC, such as the loss of DOC fluorescence (DOCF) or photobleaching, due to degradation of the chromophores (Del Vecchio and Blough, 2002). Therefore, decreases in DOCF may be used as a proxy for the amount of photoreactive intermediates that can influence the speciation of $\mathrm{Hg}$.

The present study investigates the diurnal dynamics of DGM concentration and DOCF across lakes and wetlands of varying humic content and quality. The objective is to identify a possible link between photoreactants generated during CDOC bleaching and photoreduction of $\mathrm{Hg}$ (II). The wavelength-dependency of DGM photo-induced production and of losses in DOC fluorescence is also addressed here.

\section{Materials and methods}

2.1. Study site

The study was carried out during the summers of 2002 and 2003 on one wetland, one beaver pond and four lakes (Table 1), which were chosen to represent a spectrum from clear water to highly humic conditions (DOC: 4.3 to 17.7 mg $\cdot \mathrm{L}^{-1}$; DOCF: 11 to 90 QSU). The Bay St. François wetland is adjacent to Lake St. Pierre, a fluvial lake of the St. 
(C) 2005. This manuscript version is made available under the CC-BY-NC-ND 4.0 license http://creativecommons.org/licenses/bync-nd/4.0/

https://www.sciencedirect.com/science/article/pii/S0016703704008531

Lawrence River. The lakes and the beaver pond are located in the Canadian Shield, 80 km north of Montreal. All lakes have a circumneutral $\mathrm{pH}$, and are oligotrophic or mesooligotrophic, with mean total phosphorus (TP) concentrations between 3.8 and $14.0 \mu \mathrm{g} \cdot \mathrm{L}^{-1}$. Lake Violon, used as a reservoir by the town of Mont Roland, has the clearest water, whereas lakes Cromwell and Ours have brown waters owing to their large drainage ratio and to the presence of wetlands in their watersheds. The beaver pond is small ( $<2 \mathrm{ha})$ and highly colored.

Table 1 . Location and chemistry of the study systems. ${ }^{a}$

\begin{tabular}{|c|c|c|c|c|c|c|c|}
\hline System & Location & $\begin{array}{c}\text { DOC } \\
\left({\left.\mathrm{mg} \cdot \mathrm{L}^{-1}\right)}_{2002}\right.\end{array}$ & $\begin{array}{c}\text { DOC } \\
\left(\mathrm{mg}^{-1} \mathrm{~L}^{-1}\right) \\
2003\end{array}$ & $\begin{array}{c}\mathrm{pH} \\
2002\end{array}$ & $\begin{array}{c}\varepsilon_{\mathrm{PAR}} \\
\left(\mathrm{m}^{-1}\right) \\
2002\end{array}$ & $\begin{array}{c}\mathrm{DOCF}_{0} \\
(\mathrm{QSU}) \\
2002\end{array}$ & $\begin{array}{c}\text { Total Hg } \\
\left(\mathrm{ng} \cdot \mathrm{L}^{-1}\right) \\
2002\end{array}$ \\
\hline Lake Violon & $45^{\circ} 56^{\prime} \mathrm{N}, 74^{\circ} 00^{\prime} \mathrm{W}$ & 4.3 & 4.7 & 7.4 & 0.44 & 11.3 & 1.02 \\
\hline Lake Croche & $45^{\circ} 59^{\prime} \mathrm{N}, 74^{\circ} 01^{\prime} \mathrm{W}$ & 5.6 & 5.2 & 7.2 & 0.61 & 16.2 & 1.09 \\
\hline Lake Ours & $45^{\circ} 58^{\prime} \mathrm{N}, 74^{\circ} 04^{\prime} \mathrm{W}$ & 7.4 & 7.5 & 7.6 & 1.23 & 28.0 & 1.89 \\
\hline Lake Cromwell & $45^{\circ} 59^{\prime} \mathrm{N}, 74^{\circ} 00^{\prime} \mathrm{W}$ & 8.9 & 6.2 & 6.9 & 1.55 & 32.8 & 1.45 \\
\hline Beaver pond & $45^{\circ} 89^{\prime} \mathrm{N}, 73^{\circ} 95^{\prime} \mathrm{W}$ & 6.5 & - & 6.6 & - & 31.1 & 1.69 \\
\hline Bay St François & $46^{\circ} 06^{\prime} \mathrm{N}, 74^{\circ} 17^{\prime} \mathrm{W}$ & 17.7 & - & 7.4 & - & 90.2 & 2.70 \\
\hline
\end{tabular}

${ }^{\mathrm{a}} \mathrm{DOCF}_{0}$ indicates DOC fluorescence of prior incubations. QSU, quinine sulfate unit $=1$ ppb quinine sulfate in $0.05 \mathrm{M} \mathrm{H}_{2} \mathrm{SO}_{4}$; $\varepsilon_{\mathrm{PAR}}$

$=$ photosynthetically active radiation extinction coefficient.

\subsection{Experiments}

Subsurface water samples were collected in a macrophyte-free area of the wetland, in the middle of the beaver pond, and over the deepest portion of the lakes. All samples were taken between midnight and 04:00 A.M. to avoid the presence of photoreactive radicals before the beginning of the experiments. Quartz bottles $(\varnothing 8 \mathrm{~cm} \times 40 \mathrm{~cm})$ were used in all experiments to assure complete sunlight penetration and prevent losses of $\mathrm{Hg}(0)$ through the wall. Samples were collected by hand filling quartz bottles. No headspace was present within the bottles to avoid $\operatorname{loss}$ of $\mathrm{Hg}(0) \mathrm{by}$ volatilization to the headspace. Clean procedures were adopted during sample collection and analysis: powder-free latex gloves were worn at all times; the glassware was soaked in $20 \% \mathrm{HNO}_{3}$ and rinsed with Milli-Q water, and the sampling bottles were rinsed three times with natural water before use.

The general experimental design consisted of incubating samples under natural sunlight. Quartz bottles were kept sideway, submerged in a 8-cm deep water bath which temperature was kept constant through water replacement. Water from each study site was used in the water bath. Dark controls were placed in a cooler during the incubation period. DGM analyses were performed within minutes of the end of the incubation periods.

In a first set of incubations conducted in summer 2002, diel variations in DGM concentrations and in DOCF were determined in exposed bottles, with water from all study systems. Incubation experiments began just before sunrise and lasted for $11 \mathrm{~h}$. DGM concentrations and DOCF were measured each hour or half-hour. To assess the influence of particulate matter on photo-induced DGM production in Bay St. François wetland, water samples were filtered $(0.45 \mu \mathrm{m})$ and incubations were carried out using both filtered and unfiltered samples.

In a second set of incubation experiments conducted in summer 2003, we determined the contribution of UVB, UVA and visible light on DGM photo-induced production and on variations in DOCF under a range of DOC concentrations in all study lakes. Lake water was exposed to surface solar radiation for $6 \mathrm{~h}$, from 10:00 to 16:00. Triplicate samples were distributed into three experimental treatments: (a) The first set was exposed to the full range of surface-level solar radiation; (b) the second set of samples was wrapped in Mylar filter (DuPont) to shield off the UVB waveband; (c) the third set was covered in Lee filter Model 226 (Lee, CA, USA) to shield off the UVA and UVB wavebands. The wavelength cutoff of the filters was determined using an Optronics 752 Spectroradiometer. Cutoff values corresponded to $314 \mathrm{~nm}$ and $392 \mathrm{~nm}$ for Mylar and Lee filters, respectively. Mylar filter transmitted 2.3\% of incoming UVB, $80.2 \%$ of incoming UVA, and $88.8 \%$ of visible light. Lee filter transmitted $0.1 \%$ of incoming UVB, $4.5 \%$ of incoming UVA, and $90.3 \%$ of visible light. DGM and DOCF were measured prior and after the incubations for observation of treatment effects. The photo-induced production rate of DGM (PRD) was calculated using the following equation:

$$
\mathrm{PRD}=\left([\mathrm{DGM}]_{\mathrm{t}}-[\mathrm{DGM}]_{0}\right) / t
$$

where $[\mathrm{DGM}]_{\mathrm{t}}$ and $[\mathrm{DGM}]_{0}$ are DGM concentrations at time $t$ and at the onset of the incubations, respectively; $t$ is the incubation time. 
(C) 2005. This manuscript version is made available under the CC-BY-NC-ND 4.0 license http://creativecommons.org/licenses/bync-nd/4.0/

https://www.sciencedirect.com/science/article/pii/S0016703704008531

To determine whether the availability of photoreducible mercury limits the photo-induced production of DGM, a third experiment was conducted on August 12 and 13, 2003 using, simultaneously, clear and brown waters collected in Lake Croche and in Bay St. François wetland, respectively. Three purged samples of each system with no headspace were initially incubated from 6:00 to 20:00, and then purged again with $\mathrm{Hg}$-free air for 15 min, to cause the exhaustion of photoreducible $\mathrm{Hg}$ (II). Thereafter, the samples were reincubated at the following successive intervals: from 23:00 to 5:00, from 6:00 to 10:00, from 11:00 to 15:00, and from 16:00 to 20:00. Following each incubation interval, DGM concentrations were measured as described bellow. It was assumed that, following purging, all samples were DGMfree. All diurnal incubations were conducted under cloudless conditions.

\subsection{Laboratory analysis}

For DGM determinations, 250 or $500 \mathrm{~mL}$ of water was slowly decanted into 1-L glass bubblers and purged for 15 min with Hg-free air with a Tekran 1100 zero air generator. The volatile Hg compounds were trapped on a gold-coated sand column which was then placed in an argon gas stream. The trap was dried for 3 min and $\mathrm{Hg}$ was subsequently desorbed by pyrolysis at a flow rate of $60 \mathrm{~mL} \cdot \mathrm{min}^{-1}$, using the double amalgamation technique. Hg was quantified by gas-phase atomic fluorescence spectrometry with Tekran Hg analyzer model 2500. Quality control was achieved through the intercalibration of two similar analytical lines, as well as by processing 5 or 6 system blank checks before the beginning of the analysis. For the intercalibration, water from Lake Croche was collected $\sim 4$ h after sunset to minimize the influence of photoreductants or photooxidants. Samples $(n=30)$ were taken using either quartz or Teflon bottles, stored in a cooler, and DGM was immediately measured simultaneously in the two analytical lines. Results from this intercalibration exercise indicated a good correspondence between the two lines: $91.6 \pm 6.3 \mathrm{pg} \cdot \mathrm{L}^{-1}$ and $88.9 \pm 4.8 \mathrm{pg} \cdot \mathrm{L}^{-1}$. Analytical blanks for the different experiments averaged 6.7 to $9.4 \mathrm{pg} \cdot \mathrm{L}^{-1}$, and mean detection limit $\left(3 \times \mathrm{SD}\right.$ of blancs) for a $\sim 500-\mathrm{mL}$ sample was $7.4 \pm 1.1 \mathrm{pg} \cdot \mathrm{L}^{-1}$.

Total $\mathrm{Hg}$ in water was determined in duplicate samples using atomic fluorescence spectrometry, following $\mathrm{BrCl}$ oxidation $/ \mathrm{SnCl}_{2}$ reduction, according to EPA method 1631. Analytical blank averaged $0.092 \mathrm{ng} \cdot \mathrm{L}^{-1}$, and the detection limit for a $60-\mathrm{mL}$ sample was $0.099 \mathrm{ng} \cdot \mathrm{L}^{-1}$.

Photochemical transformations of DOC were followed with fluorescence measurements done in parallel with DGM determinations. DOC fluorescence (DOCF) was measured with a Perkin-Elmer 204 spectrofluorometer equipped with a $10 \times 10 \mathrm{~mm}$ quartz cuvette, at $355 \mathrm{~nm}$ excitation and $455 \mathrm{~nm}$ emission wavelengths. The average coefficient of variation for samples analyzed in triplicate during summer 2003 corresponded to $0.8 \%$. A $0.05 \mathrm{M} \mathrm{H}_{2} \mathrm{SO}_{4} \mathrm{Solution}_{\text {was }}$ used as a blank. Values were calibrated against the fluorescence of quinine sulfate using standard solutions, with one quinine sulfate unit $(\mathrm{QSU})=1 \mathrm{ppb}$ quinine sulfate in $0.05 \mathrm{M} \mathrm{H}_{2} \mathrm{SO}_{4}$. DOCF bleaching was calculated as percent losses of DOCF at time $t$ relatively to DOCF at the beginning of the incubations $\left(\mathrm{DOCF}_{0}\right)$.

Samples for DOC determination were filtered on washed Gelman Supor 0.45- $\mu$ m membranes. DOC was measured with a Shimadzu TOC-5000 by infrared gas analysis after sample acidification and He sparging, followed by Pt catalyzed oxidation at $700^{\circ} \mathrm{C}$.

\subsection{Light measurements}

Surface irradiance was measured at the UV and photosynthetically active radiation (PAR, 400-700 nm) ranges with a spectroradiometer ASD FieldSpec Pro. Surface irradiance was recorded at 10-min intervals and integrated for the period of incubation. PAR extinction coefficient $\left(\varepsilon_{\mathrm{PAR}}\right)$ was measured using a Li-Cor LI-192SA sensor. Light extinction coefficients with depth $\left(\mathrm{k}_{\mathrm{d}}\right)$ for UVB and UVA were approximately estimated following the models proposed by Scully and Lean (1994) for Canadian Shield lakes:

$$
\begin{aligned}
& \mathrm{k}_{\mathrm{d}} \text { UVB }=0.415(\mathrm{DOC})^{1.86} \\
& \mathrm{k}_{\mathrm{d}} \mathrm{UVA}=0.299(\mathrm{DOC})^{1.53}
\end{aligned}
$$

Note that we did not validate these models by measuring UVB and UVA extinction coefficients. However the Scully and Lean models include lakes of the Canadian Shield displaying similar physical and chemical characteristics, and should therefore be applicable here. We did not apply the models to the Bay St. François site, because the chemistry of this site (particularly DOC levels) did not fall within the boundaries of application of the models.

Meteorological data (air temperature, wind speed, precipitation) were obtained from the Laurentian Biological Station of the Université de Montreal. 
(C) 2005. This manuscript version is made available under the CC-BY-NC-ND 4.0 license http://creativecommons.org/licenses/bync-nd/4.0/

https://www.sciencedirect.com/science/article/pii/S0016703704008531

\subsection{Kinetics of sunlight-induced $\mathrm{Hg}(\mathrm{II})$ reduction}

Previous studies have clearly shown that solar radiation induces both DGM production and oxidation (Amyot et al., 1994; Lalonde et al., 2001, 2004). Hence, DGM concentrations observed in our experiments over the course of the day represent a net balance between $\mathrm{Hg}(\mathrm{II})$ photoreduction and $\mathrm{Hg}^{0}$ photooxidation:

$$
\mathrm{d}[\mathrm{DGM}] / \mathrm{dt}=\mathrm{k}_{1} *\left[\mathrm{Hg}_{\mathrm{tot}}\right]-\mathrm{k}_{2} *[\mathrm{DGM}]
$$

where $\mathrm{k}_{1} *\left[\mathrm{Hg}_{\text {tot }}\right]$ is the rate of formation of DGM and $\mathrm{k}_{2} *[\mathrm{DGM}]$ is the rate of oxidation back to $\mathrm{Hg}$ (II). Assuming that the total mercury mass is conserved, the integrated model yields:

$$
[D G M]_{\mathrm{t}}=\left(\mathrm{k}_{1} /\left(\mathrm{k}_{1}+\mathrm{k}_{2}\right)\right) *\left[\mathrm{Hg}_{\text {tot }}\right] *\left(1-\mathrm{e}^{-\left(\mathrm{k}_{1}+\mathrm{k}_{2}\right) \mathrm{t}}\right)
$$

Taking into account that DGM concentration at the beginning of the experiments ([DGM $])$ is not zero, we can include it to Eqn. $\underline{5}$, as a correction factor:

$$
[\mathrm{DGM})_{\mathrm{t}}=[\mathrm{DGM}]_{0}+\left(\mathrm{k}_{1} /\left(\mathrm{k}_{1}+\mathrm{k}_{2}\right)\right) *\left[\mathrm{Hg}_{\mathrm{tot}}\right] *\left(1-\mathrm{e}^{-\left(\mathrm{k}_{1}+\mathrm{k}_{2}\right) \mathrm{t}}\right)
$$

Since solar irradiance varies as a function of time of the day, DGM concentration can also be estimated as a function of cumulative solar radiation (y), instead of time (t) (O’Driscoll et al., 2004):

$$
[\mathrm{DGM}]_{\mathrm{t}}=[\mathrm{DGM}]_{0}+\left(\mathrm{k}_{1} /\left(\mathrm{k}_{1}+\mathrm{k}_{2}\right)\right) *[\mathrm{Hg}]_{\mathrm{tot}} *\left(1-\mathrm{e}^{-\left(\mathrm{k}_{1}+\mathrm{k}_{2}\right) \mathrm{y}}\right)
$$

It is clear from the Eqn. 7 that the DGM levels show a nonlinear and pseudoexponential behavior relatively to variations in light intensity. This model describes a direct photoreduction of $\mathrm{Hg}$ and our data follow it closely. However, this does not exclude the possibility of an indirect mechanism for $\mathrm{Hg}(\mathrm{II})$ photoreduction, since the formation of potential reaction intermediates can also covary with light.

Finally, it should be noted that all curve fitting was done using Statgraphics*Plus, version 2.1 (Manugistics).

\section{Results}

\subsection{Diurnal variations in DGM}

In all aquatic systems except for Lake Croche, variations in DGM concentration in incubation bottles were well described by Eqn. $\underline{7}$ ( $R^{2}$ between 0.76 and $0.92, p<0.0001$, Fig. 1 ). In these systems, DGM increased with cumulative solar radiation and then tended to reach a plateau. In Lake Croche, DGM levels increased from sunrise until early afternoon, decreasing afterward. DGM concentrations at the onset of incubations $\left(\mathrm{DGM}_{0}\right)$ varied from $13 \mathrm{pg} \cdot \mathrm{L}^{-1}$ to $76 \mathrm{pg} \cdot \mathrm{L}^{-1}$ and mean [DGM] at the plateau, from $66 \mathrm{pg} \cdot \mathrm{L}^{-1}$ to $280 \mathrm{pg} \cdot \mathrm{L}^{-1}$. Although $\mathrm{DGM}_{0}$ concentrations in both filtered and unfiltered water from Bay St. François wetland were similar, the DGM plateau for the filtered water was around $30 \%$ higher than for unfiltered water. 
(C) 2005. This manuscript version is made available under the CC-BY-NC-ND 4.0 license http://creativecommons.org/licenses/bync-nd/4.0/

https://www.sciencedirect.com/science/article/pii/S0016703704008531

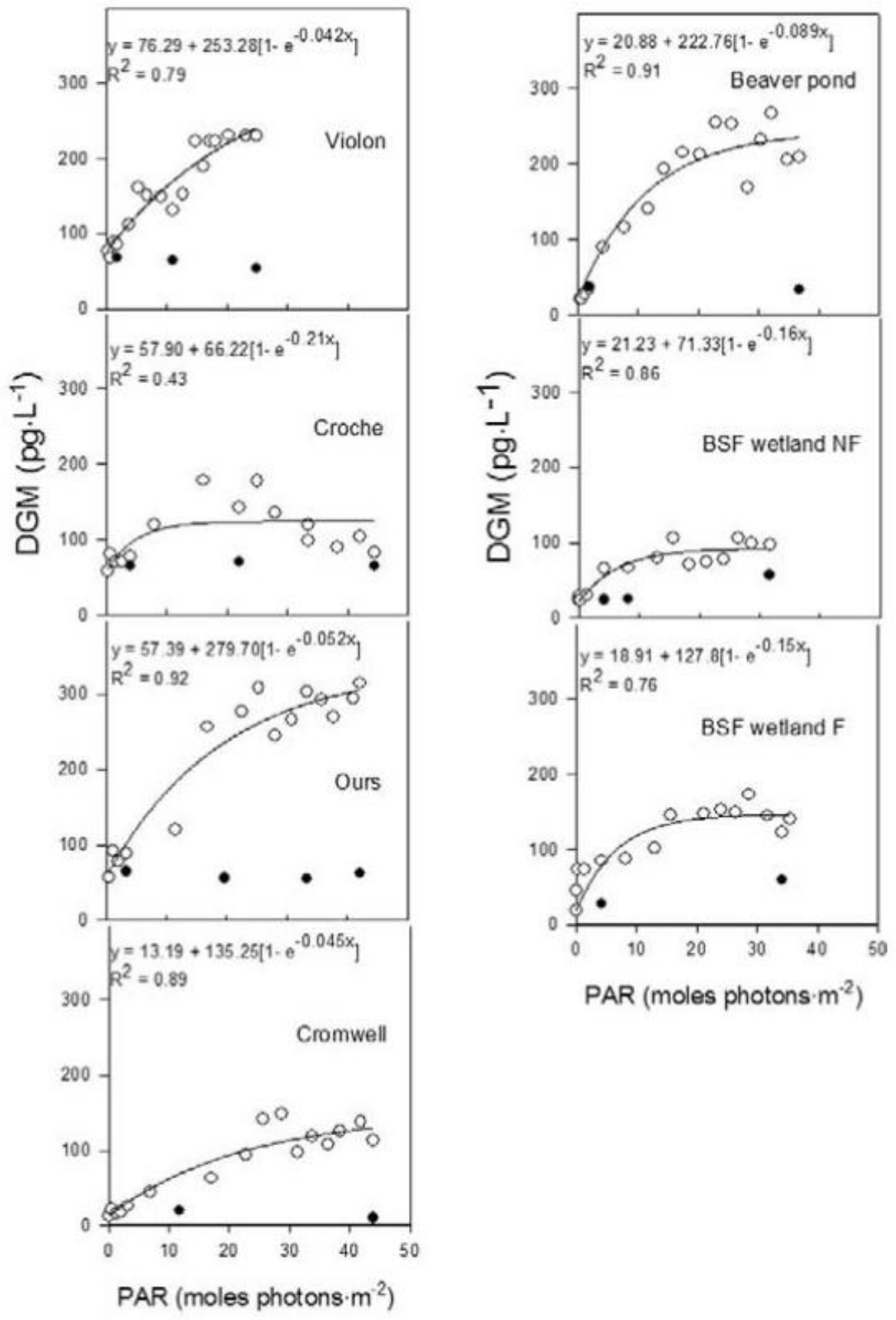

Fig. 1. Diurnal variations in DGM as a function of cumulative PAR in all study systems in August 2002. Solid line represents regression for the equation showed in the graph. Open circles indicate sunlight exposed samples; closed circles correspond to dark control.

Maximum DGM levels ( $\mathrm{DGM}_{\max }$ ) observed following sunlight exposure varied from one system to another, ranging from $106 \mathrm{pg} \cdot \mathrm{L}^{-1}$ to $315 \mathrm{pg} \cdot \mathrm{L}^{-1}$. These values represented from 4 to $23 \%$ of total $\mathrm{Hg}$ in the study systems. The $\%$ of total $\mathrm{Hg}$ as DGM was negatively related to DOC concentrations ( $\underline{\text { Fig. } 2}, r=-0.95, p=0.001)$. 
(C) 2005. This manuscript version is made available under the CC-BY-NC-ND 4.0 license http://creativecommons.org/licenses/bync-nd/4.0/

https://www.sciencedirect.com/science/article/pii/S0016703704008531

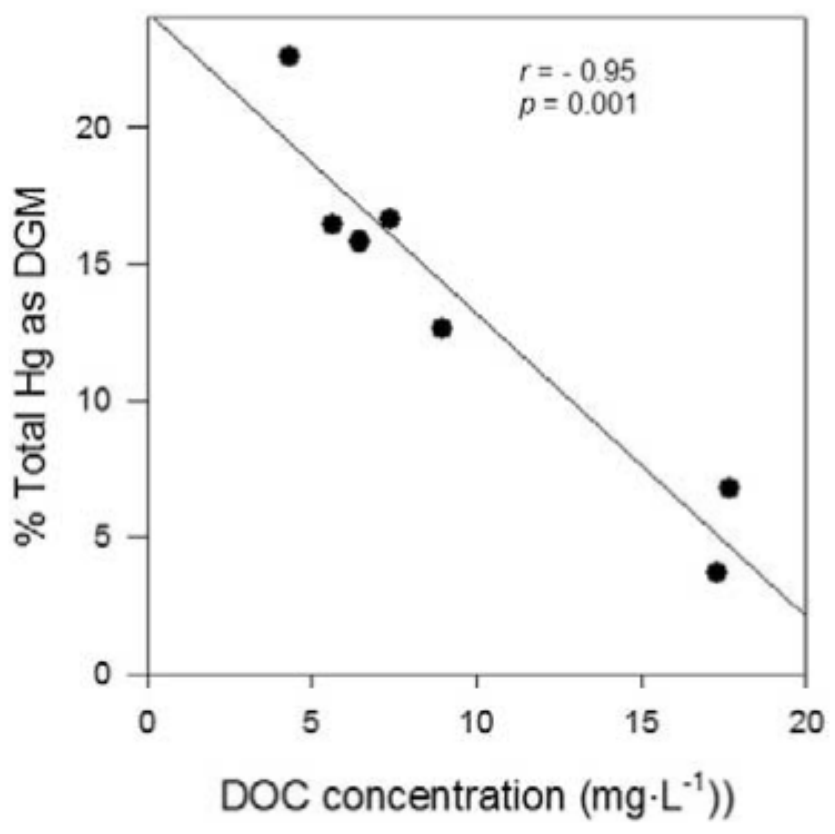

Fig. 2. Linear correlation between $\%$ of total $\mathrm{Hg}$ as DGM and DOC concentration in all study systems in August 2002.

DGM concentrations in dark controls were consistently lower than in light treatment (Fig. 1) in all study systems. In the Bay St. François wetland, an increase in DGM levels in the dark was observed both in unfiltered and in $0.45-\mu \mathrm{m}$ filtered water during the 11-h incubation period.

In Lake Croche and in Bay St. François wetland, photoreduction of $\mathrm{Hg}(\mathrm{II})$ continued in samples successively reincubated, from which the formed $\mathrm{Hg}^{0}$ was removed between incubations (Fig. 3). In both systems, DGM concentrations tended to vary with sunlight intensity $(r=0.89 ; p<0.01)$, peaking in the middle of the day. In the wetland samples, a production of DGM was also observed during the night. 
(C) 2005. This manuscript version is made available under the CC-BY-NC-ND 4.0 license http://creativecommons.org/licenses/bync-nd/4.0/

https://www.sciencedirect.com/science/article/pii/S0016703704008531
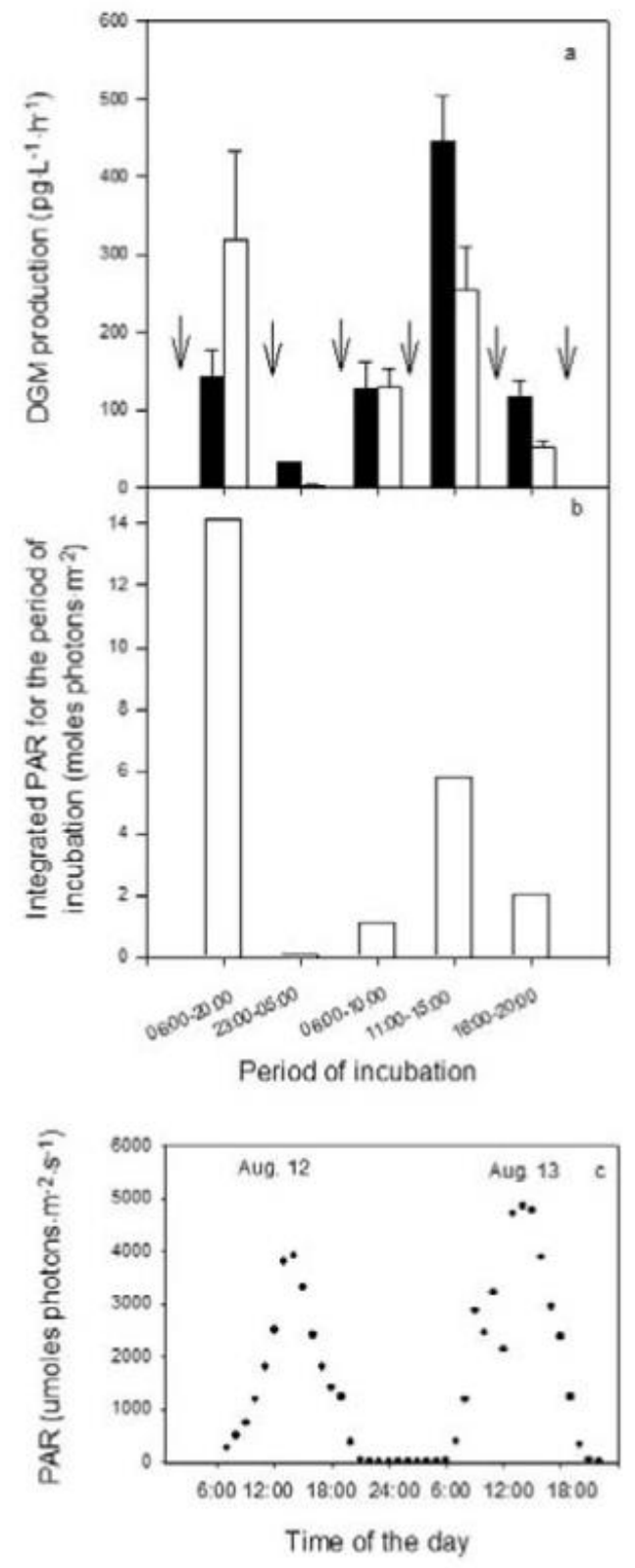

Fig. 3. (a) Mean DGM production observed on August 12 and 13, 2003, in triplicate samples from Lake Croche (white bars) and Bay St. François wetland (black bars) incubated in successive periods of the day and completely purged (arrows) at the beginning of the experiment and following each period of incubation. Error bars represent SD. (b) Integrated PAR for the incubation periods. (c) Diurnal variations in PAR for the $2 \mathrm{~d}$ of incubation. 
(C) 2005. This manuscript version is made available under the CC-BY-NC-ND 4.0 license http://creativecommons.org/licenses/bync-nd/4.0/

https://www.sciencedirect.com/science/article/pii/S0016703704008531

\subsection{Diurnal variations in DOC}

DOCF varied from 11 QSU to 90 QSU. Taking into account their DOCF range, the study systems could be divided into three groups (Fig. 4): the first one consisting of lakes Violon and Croche (DOCF < 20 QSU), the second one including lakes Ours and Cromwell, as well as the beaver pond (DOCF between 20 and 35 QSU) and the third group comprising filtered and unfiltered water from the Bay St. François wetland (DOCF > 60 QSU). DOCF before incubations $\left(\mathrm{DOCF}_{0}, \underline{\text { Table } 1}\right)$ was strongly correlated to DOC concentrations $(r=+0.98, p<0.001)$. DOCF in filtered water from the Bay St. François wetland was slightly but significantly lower than in unfiltered waters (Fig. 4$)$.

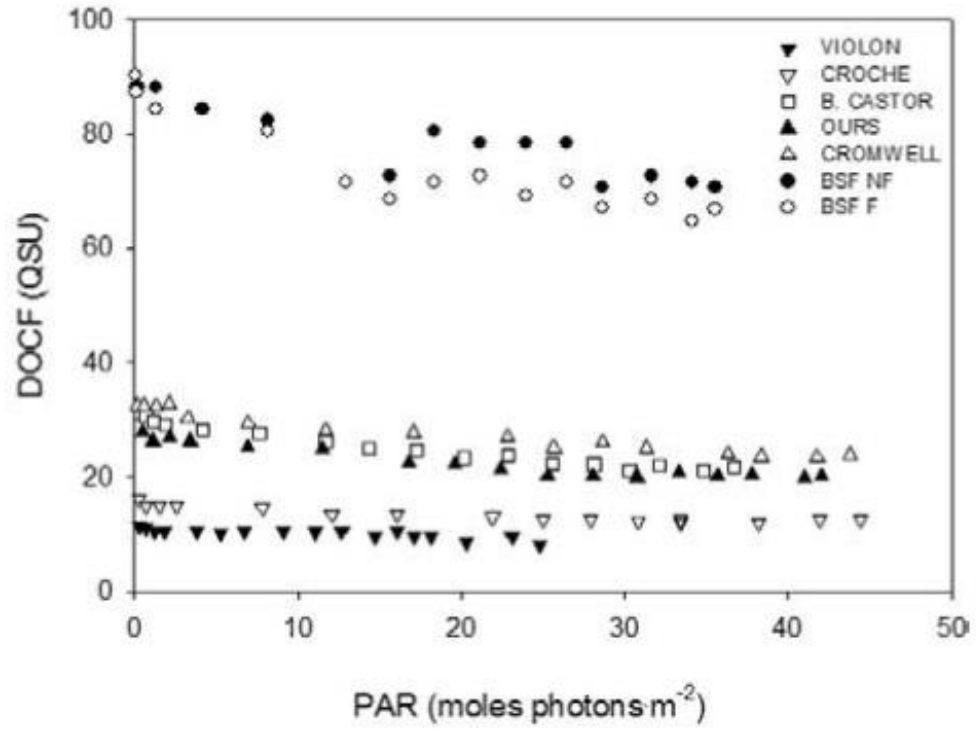

Fig. 4. Diurnal variations in DOC fluorescence in quinine sulfate unit (QSU) as a function of cumulative PAR in all study systems in August 2002 .

Similarly to DGM concentrations, DOCF bleaching in incubation bottles increased exponentially with cumulative solar radiation (Fig. 5). At the beginning of the day, before exposure to sunlight, negative values of DOCF bleaching were observed. As sunlight faded, over the course of the afternoon, a plateau tended to be reached in all systems but Lake Violon. Despite the large differences in absolute DOCF mentioned above, among-system variations in maximum DOCF bleaching were relatively low, ranging from 22 to $31 \%$ (Fig. 5). In dark controls, decreases in DOCF during the 11 -h incubations represented less than $5 \%$ of the initial values (between 0 and $4.5 \%$ ). 
(C) 2005. This manuscript version is made available under the CC-BY-NC-ND 4.0 license http://creativecommons.org/licenses/bync-nd/4.0/

https://www.sciencedirect.com/science/article/pii/S0016703704008531
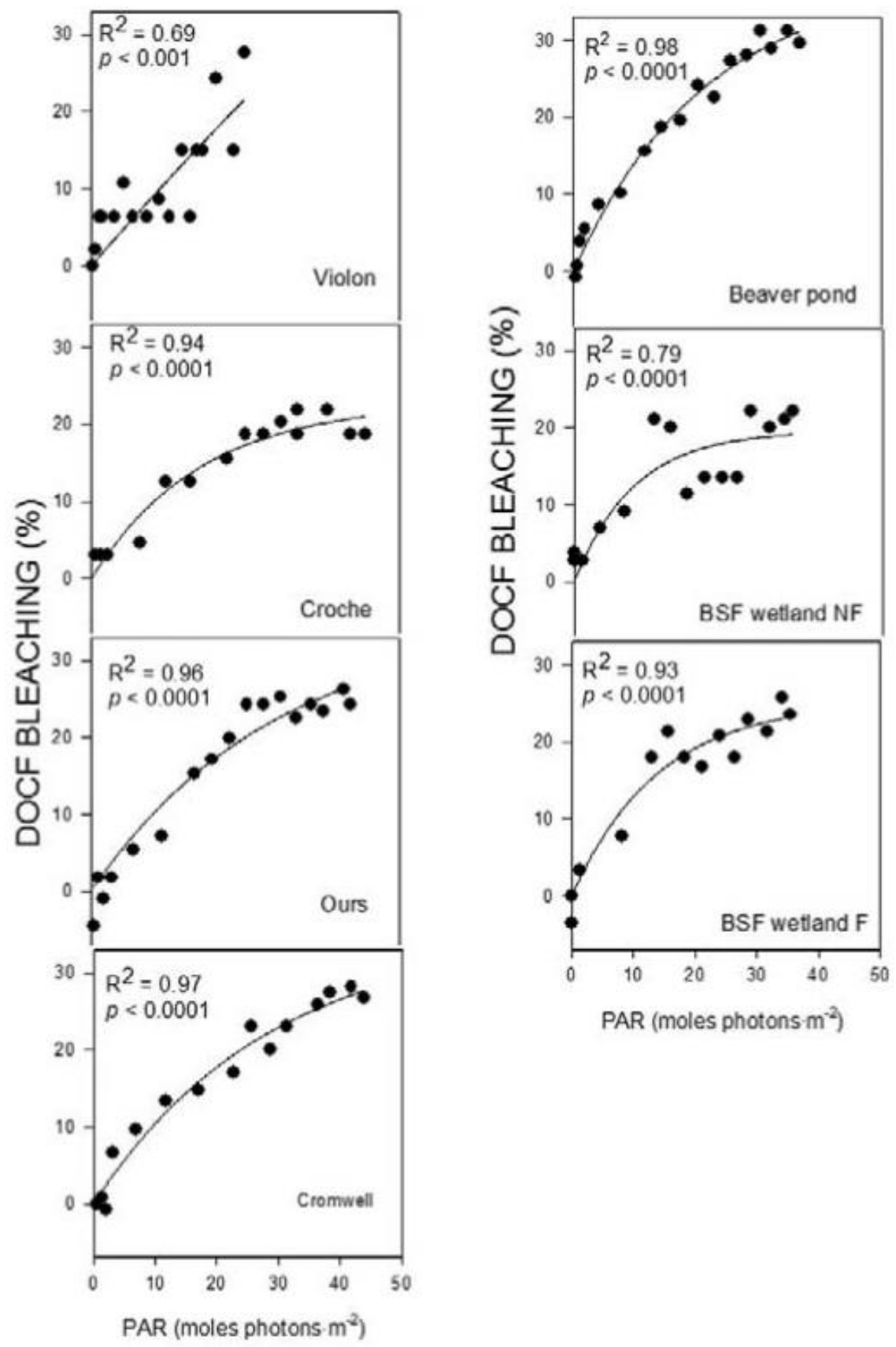

Fig. 5. Diurnal variations in DOC fluorescence bleaching during sunlight exposure in all study systems in August 2002.

\subsection{Relationship between DGM photo-induced production and losses in DOCF}

The positive relationships between diurnal variations in DGM and losses in DOCF in the different systems were fitted with sigmoid models (Fig. 6). The S-curves yielded a lower mean square error than linear and exponential regressions, with losses in DOCF explaining between 67 and 96\% of the variations in DGM. For Lake Croche, adequate description of variations in DGM production was only provided under low DOCF bleaching $(<5 \%)$ using the sigmoid model. For the remaining systems, a slow initial increase in DGM production at low DOCF bleaching, at the beginning of the 
(C) 2005. This manuscript version is made available under the CC-BY-NC-ND 4.0 license http://creativecommons.org/licenses/bync-nd/4.0/

https://www.sciencedirect.com/science/article/pii/S0016703704008531

day, was followed by a subsequent acceleration phase over the course of the day, tending to a plateau (the higher asymptote), at DOCF losses higher than $15 \%$.
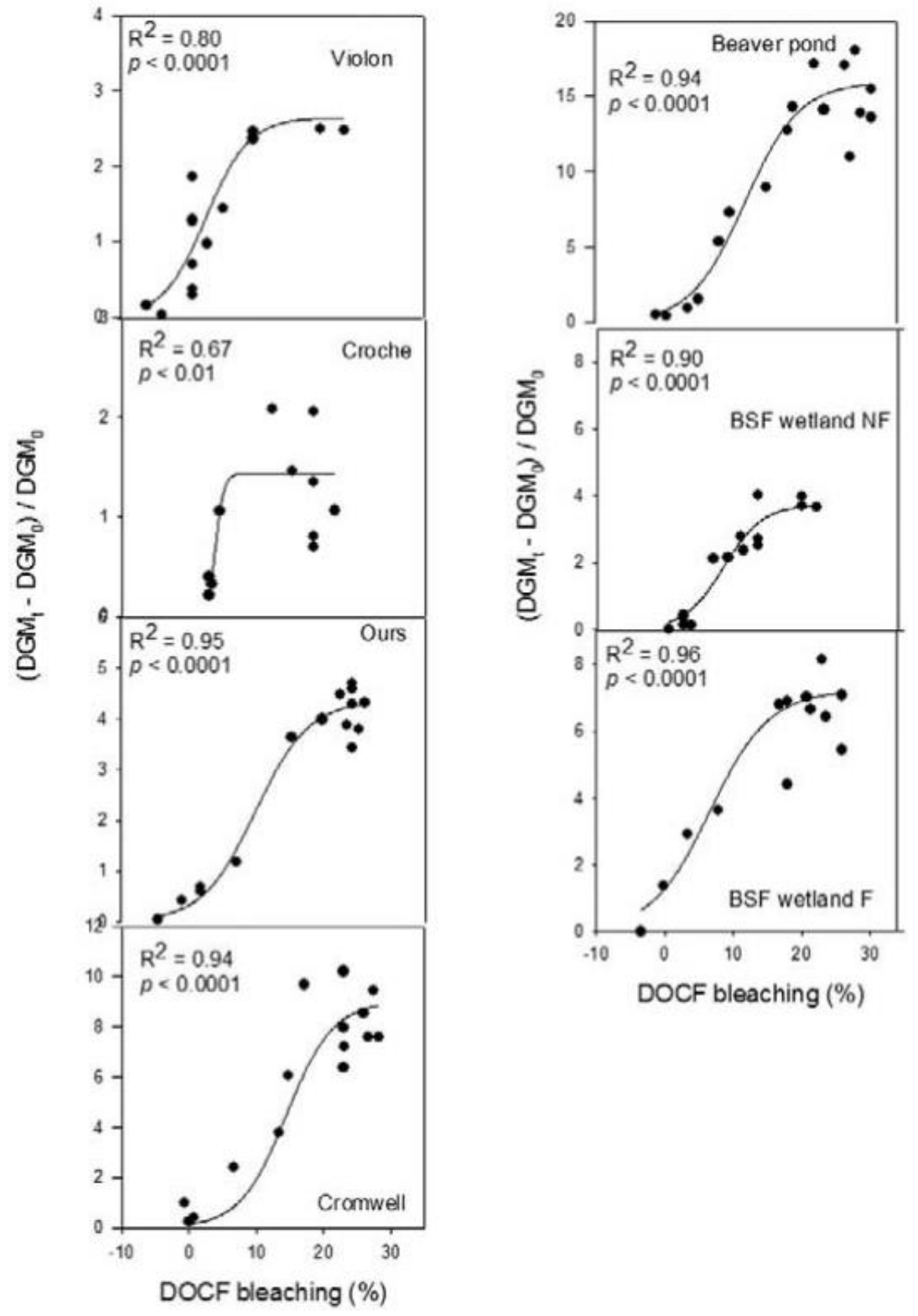

Fig. 6. Relationship between DOCF bleaching and DGM variations relatively to concentrations at the onset of the incubations in all study systems in August 2002. 
(C) 2005. This manuscript version is made available under the CC-BY-NC-ND 4.0 license http://creativecommons.org/licenses/bync-nd/4.0/

https://www.sciencedirect.com/science/article/pii/S0016703704008531

3.4. The importance of different wavebands in the DGM photo-induced production and DOCF losses

Under the full solar spectrum, the rates of photo-induced DGM production ranged from $14 \mathrm{pg} \cdot \mathrm{L}^{-1} \cdot \mathrm{h}^{-1}$ to 32 $\mathrm{pg} \cdot \mathrm{L}^{-1} \cdot \mathrm{h}^{-1}$, and did not vary significantly from one lake to another (Fig. 7a). Most DGM production (61 to $\left.73 \%\right)$ occurred under UV radiation (UVA + UVB), whereas visible light alone accounted for at most $27 \%$ of the DGM photo-induced production. Under UVB radiation, the highest rates of DGM formation were observed in the clearest lakes, Violon and Croche. Inversely, under UVA radiation, DGM production rates tended to be higher in the humic lakes, Ours and Cromwell. In fact a strong positive correlation was observed between DGM production under UVA and DOC concentrations (Fig. 8a), whereas DGM production under UVB was negatively correlated to DOC (Fig. 8b). In all dark controls, variations in DGM concentration for the 6-h incubation period were not significant.

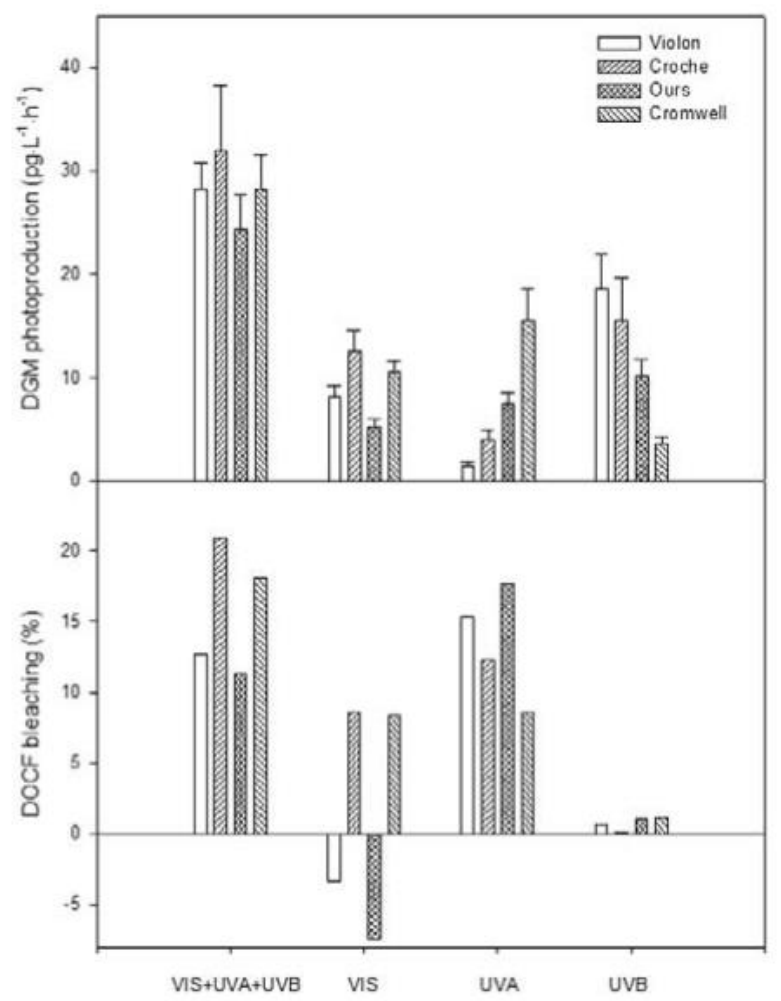

Fig. 7. (a) DGM photo-induced production and (b) losses in DOC fluorescence in water from lakes Violon, Croche, Cromwell and Ours incubated for $6 \mathrm{~h}$ under different sunlight wavelengths in July 2003. 
(C) 2005. This manuscript version is made available under the CC-BY-NC-ND 4.0 license http://creativecommons.org/licenses/bync-nd/4.0/

https://www.sciencedirect.com/science/article/pii/S0016703704008531

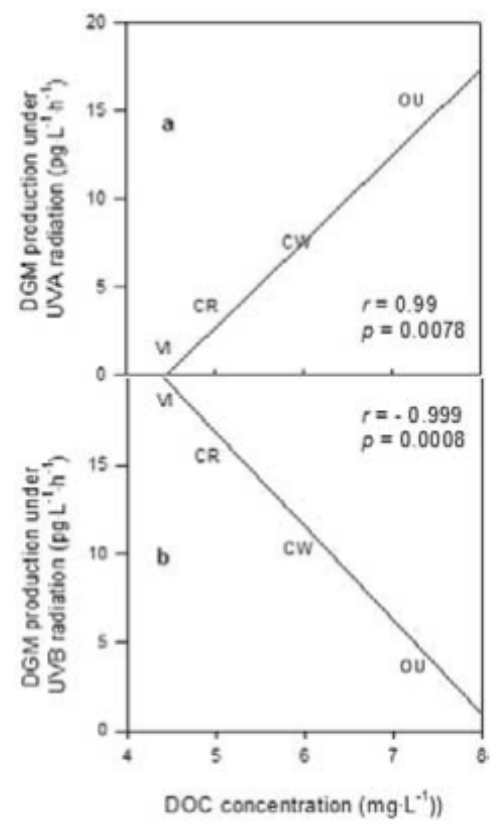

Fig. 8. Linear correlations between DGM photo-induced production and DOC concentration in water from lakes Violon, Croche, Cromwell and Ours incubated for $6 \mathrm{~h}$ under (a) UVA and (b) UVB radiation in July 2003.

A 6-h exposure of samples to the full spectrum of incident sunlight reduced DOCF by up to $21 \%$, with the highest losses being observed in water from Lake Croche and the lowest in Lake Ours (11\%) (Fig. 7b). The largest declines in DOCF were induced by UVA radiation in the four lakes, whereas effects of UVB were minor. Under visible light alone, either losses (Croche and Cromwell) or recoveries (Violon and Ours) in DOCF were observed.

\section{Discussion}

\subsection{DOCF and diurnal variations in DGM}

In natural waters, diurnal changes in DGM concentrations are the net result of the difference in DGM production and DGM removal through evasion to the atmosphere or through oxidation (Fitzgerald et al., 1994; Lalonde et al., 2001, 2004). The strong correlation between DGM concentrations and solar radiation dose observed in this study corroborates previous findings reporting that the primary $\mathrm{Hg}$ (II) reduction mechanism is photo-mediated (Amyot et al., 1994). The measured increases in DGM showed that, following sunlight exposure, the production rates tended to be initially faster than the oxidation rates in all systems, independently of DOC concentration. Subsequently, as sunlight faded, DGM concentrations reached a plateau or decreased (Lake Croche). Comparable diurnal trends in DGM have been reported in other lakes with different DOC levels (Amyot et al., 1997a; O'Driscoll et al., 2004). Since the experiments were conducted in closed quartz bottles without any headspace left, decreases in DGM were not the result of volatilization through the walls or in the headspace of the sample. Rather, under low light intensity, oxidation of $\mathrm{Hg}^{0}$ can counterbalance or even rapidly surpass DGM formation. Indeed, we recently reported that, in Lake Croche, there was a strong diel pattern in $\mathrm{Hg}$ oxidation rates, with a peak at midday, which could explain the decrease in DGM observed here (Garcia et al., 2005).

Similarly to DGM, DOCF losses increased over the course of the day, from the morning to the early afternoon, when a plateau tended to be reached due to light attenuation, mainly in the UV range. The strong relationship between diurnal variations in DGM and losses in DOCF point to a significant role of photochemical transformations of DOC in the photoreduction of $\mathrm{Hg}(\mathrm{II})$. It is known that a large portion of photons arriving in natural waters is absorbed by chromophoric dissolved organic carbon (CDOC). The excited CDOC can then act as sensitizer or can generate 
(C) 2005. This manuscript version is made available under the CC-BY-NC-ND 4.0 license http://creativecommons.org/licenses/bync-nd/4.0/

https://www.sciencedirect.com/science/article/pii/S0016703704008531

photoreactive intermediates, such as hydrogen peroxide $\left(\mathrm{H}_{2} \mathrm{O}_{2}\right)$, hydroxyl radicals $\left(\mathrm{OH}^{*}\right)$, DOM-derived peroxy radicals (ROO*), triplet states of humic compounds and aquated electron ( $\mathrm{e}^{-}$aq) (Leifer, 1988; Stumm and Morgan, 1996). These photoreactants are able to alter redox conditions, and their production is positively related to DOCF loss. For instance, similar diurnal dynamics of $\mathrm{H}_{2} \mathrm{O}_{2}$ and losses in dissolved organic matter fluorescence has been observed in marine water (Obernosterer et al., 2001), and hydrogen peroxide has been proposed as a potential Hg reducing agent under neutral to alkaline conditions (Schroeder et al., 1991), which is plausible in the study systems given their $\mathrm{pH}$ range. Altogether these findings suggest that availability of photoreductants can be the limiting step in the DGM production. Contrary to previous studies where photoreducible mercury has been proposed as the factor limiting the photoreduction of $\mathrm{Hg}$ (II) (Fitzgerald et al., 1994; O'Driscoll et al., 2004), the plateau in DGM concentrations observed in the study systems does not seem to be related to limitation of substrate to $\mathrm{Hg}$ (II) reduction, but is more likely the result of a balance between oxidation and reduction. Indeed, successive incubations of waters from a clear lake (Lake Croche) and from the wetland, each of them followed by purging, showed that the pool of DGM could be replenished, and that the DGM production was a function of solar radiation. Therefore, the amount of photoreducible $\mathrm{Hg}$ was enough to assure photo-induced production of DGM.

The participation of DOC in photochemical reduction of $\mathrm{Hg}(\mathrm{II})$ has been proposed in freshwater, as well in sea water (Allard and Arsenie, 1991; Nriagu, 1994; Costa and Liss, 1999), but its role is a matter of controversy. According to Mason et al. (1999), the complexation by DOC reduces the concentration of $\mathrm{Hg}(\mathrm{II})$ available for reduction. Alternatively, it has been hypothesized that formation of compounds with DOC facilitates the reduction of $\mathrm{Hg}$ (II) due to direct transfer of electrons from photosensitized DOC bound to Hg (Allard and Arsenie, 1991; Tseng et al., 2004). Such discrepancies may have arisen likely because the amounts of DOC rather than its properties have been considered.

\subsection{Among-systems variations in DOCF}

DOC fluorescence was significantly higher in humic than in clear waters. Considering the diversity of the study systems - lakes, wetland, and beaver pond - the observed differences can be explained not only by DOC concentrations but also by among-system variations in the quality of the organic matter. Actually, spatial and temporal variations in DOCF can be related to the source and composition of organic carbon (allochthonous vs. autochthonous) or to intrasystem processes affecting the distribution and properties of DOC (Moran et al., 2000; McKnight et al., 2001). For instance, water residence time, euphotic zone depth, mixing, as well as inputs of DOC from the catchment area have an effect on the exposure time of DOC to solar radiation (Schindler et al., 1997) and can be key factors in the regulation of DOC photosensitivity.

Despite the variations in DOC concentration and origin, losses in DOCF, as $\%$ of $\mathrm{DOCF}_{0}$, in samples incubated during $11 \mathrm{~h}$ were comparable in all study systems, and similar to those reported elsewhere (Graneli et al., 1996). In addition, the level of bleaching at which DGM production ceased to increase was about the same in all systems. These results suggest a limitation in the DOC photodegradation and consequently in the formation of photoreductants, ultimately affecting the rate of DGM photo-induced production. A faster decline in UV radiation during the afternoon relatively to visible light could explain the observed plateau in DOCF losses.

4.3. Effects of different wavelengths on losses in DOCF and on DGM photo-induced production Photons absorption is a precondition for the occurrence of photochemical reactions. The production of photoreactants and DGM are thus expected to vary with the wavelength of the incident radiation. Indeed, exposure of water to different fractions of the solar spectrum resulted in different rates of DGM production, UV radiation being more important than visible light in the photoreduction of $\mathrm{Hg}(\mathrm{II})$ in surface water in the four lakes. It should be noted that we did not totally isolate the effect of UVB and UVA radiation from the effect of visible light, since all filters allowed visible light to penetrate. The effect of UVB on the DGM photo-induced production was more pronounced in clear lakes, whereas the importance of UVA tended to increase in humic lakes. A similar tendency has been observed by Amyot et al. (1997b) in Arctic and temperate lakes, and has been attributed to differences in UVA and UVB penetration in waters with varying DOC concentrations. In the present study, the estimated depths at which $99 \%$ of UVB and UVA radiation were absorbed ranged from $13 \mathrm{~cm}$ to $31 \mathrm{~cm}$ and from $35 \mathrm{~cm}$ to $72 \mathrm{~cm}$, respectively. In deeper waters, however, the role of visible wavelengths in the photoreduction of $\mathrm{Hg}(\mathrm{II})$ could be much greater since visible light penetrates much deeper than UV light in natural waters. Also, DGM production can be induced by photosynthetic organisms either directly (Ben-Bassat et al., 1978) or indirectly (Lanzilotta et al., 2004). The photobiological reduction of $\mathrm{Hg}$ by visible light has even been detected below the depth of UV penetration in some lakes (Poulain et al., 2004). Similarly to DGM production, DOCF was more affected by UV than by visible radiation. Losses in fluorescence were high in the UVA range and very low under UVB, in clear and in humic waters. Graneli et al. (1996) also reported an important role of UVA on losses of DOCF. A recovery of fluorescence after incubation under visible light alone was 
(C) 2005. This manuscript version is made available under the CC-BY-NC-ND 4.0 license http://creativecommons.org/licenses/bync-nd/4.0/

https://www.sciencedirect.com/science/article/pii/S0016703704008531

observed in lakes Violon and Ours. This recovery of DOCF could be related to the oxidative regeneration of DOC from particulate carbon and consequent formation of fluorescent materials (Kouassi and Zika, 1990).

We calculated the fraction of total $\mathrm{Hg}$ that could be reduced in surface waters during the period of the day before the plateau in DGM was reached (when oxidation is less important than reduction). In this calculation, we assumed that DGM photo-induced production is limited mainly to the layer at which $99 \%$ of the UVA radiation is absorbed and that no $\mathrm{Hg}$ enters the lake. In a typical summer day, $\sim 30$ and $32 \%$ of the total $\mathrm{Hg}$ pool in that layer could be potentially photoreduced to DGM in lakes Violon and Croche, respectively. In the most humic lakes, Ours and Cromwell, these percentages would correspond to 14 and $21 \%$. Although rough, these estimations indicate that photo-induced production of DGM would be more pronounced in clear water lakes, and are supported by the negative correlation between DOC concentration and the ratio of DGM to total mercury observed here and in 23 Northern Wisconsin lakes (Watras et al., 1995). Consequently, under similar wind conditions, evasion of $\mathrm{Hg}^{0}$ is likely to be more accentuated in clear waters. Moreover, if we consider that the mean depth of the layer at which $99 \%$ of the UVA radiation is absorbed in clear lakes is $\sim 63 \%$ higher than in humic lakes, the DGM photo-induced production in clear lakes relatively to the total $\mathrm{Hg}$ pool is still more important than in humic ones.

\subsection{DGM in the Bay St. François wetland: effects of filtration and dark production}

Even though DGM concentrations at the onset of the incubations were similar in filtered and unfiltered samples, DGM production in filtered water over the daytime period was $\sim 30 \%$ higher compared to the production in the unfiltered water. All other parameters being the same, it seems that the removal of particulate matter resulted in higher DOCF bleaching and consequently in higher photochemical reduction of $\mathrm{Hg}(\mathrm{II})$.

The observed DGM production during the night in samples from the Bay St. François wetland suggests the occurrence of a nonphotochemical mechanism for reduction of $\mathrm{Hg}(\mathrm{II})$. Such increases seem not to be related to the presence of particulate material, since they were also observed in dark controls either in unfiltered or in $0.45-\mu \mathrm{m}$ filtered water.

\subsection{Factors affecting photochemical production of DGM in the water column}

The assessment of the importance of DOCF losses as a mechanism influencing the photoreduction of $\mathrm{Hg}$ (II) in natural waters is complicated by a number of uncontrolled issues. Although DOCF seems to be related to DGM production in surface waters, extrapolations of the obtained results to the whole system must be perceived with caution, since photochemical reaction rates depend on accurate predictions of light penetration, which decreases exponentially with depth. Likewise, seasonal variation in CDOC photobleaching can have repercussions on the production of DGM in the photic zone. In this study, photoreduction was estimated in midsummer, when it was potentially at its maximal. At this period, the stratification of the water column results in the entrapping of DOC in the epilimnion, leading to the exposure of DOC to high irradiation intensities, and preventing lost of DOC to deeper water layers. As water column mixing increases, sunlight unexposed DOC is continually added to the photoactive layer. However, this increase in the unexposed DOC pool does not necessarily enhance the rate of CDOC photobleaching, since mixing processes correspond to periods of attenuated UV radiation, relatively to summer time. Therefore, a more detailed study is needed to understand how mixing processes may affect DOC-mediated $\mathrm{Hg}$ (II) photoreduction.

Windy conditions, besides favoring DGM evasion to the atmosphere, can also strongly affect the rates and distribution of photoreactions in the water column. To compare variations in DOCF in the absence and in the presence of wind, DOCF was measured over the course of a moderately windy day (average wind speed $\sim 3 \mathrm{~m} \cdot \mathrm{s}^{-1}$ ) in incubated and nonincubated subsurface water from Lake Croche (Fig. 9). The general diurnal trends in DOCF were similar in closed and open systems. DOCF losses, however, were more noticeable in the quartz bottles, suggesting that, under calm conditions, photo-processes affecting $\mathrm{Hg}$ (II) reduction at the top of the water column may be important, especially in humic waters, where light penetration is limited to a few centimeters of depth. On the other hand, windy conditions would constantly renew $\mathrm{Hg}(\mathrm{II})$ and $\mathrm{CDOC}$ in the photoactive layer.

Taken together, the results obtained in this study suggest that DOCF bleaching can be an indicator of the photoreduction of $\mathrm{Hg}(\mathrm{II})$ in surface waters. There are also indications that DGM photo-induced production is more important in clear than in humic waters. In addition, DGM formation varies with the wavelength of the incident radiation, likely due to differences in UVA and UVB penetration in waters with varying humic content.

At the air/water interface of temperate boreal lakes, one can expect an annual cycle of DGM photoproduction, with summer maxima, resulting mainly from changes in the intensity and quality of solar radiation during the ice-free season, and low rates of DGM photoproduction during the winter, due to near darkness conditions. Superimposed on 
(C) 2005. This manuscript version is made available under the CC-BY-NC-ND 4.0 license http://creativecommons.org/licenses/bync-nd/4.0/

https://www.sciencedirect.com/science/article/pii/S0016703704008531

the basic cycle, DGM photoproduction will be also affected by annual changes in the quality of the DOC (and of its fluorescence), with important inputs of fresh DOC during spring, and a slow photodegradation of DOC during the summer months, particularly in shallow systems (Amyot et al. 2004).

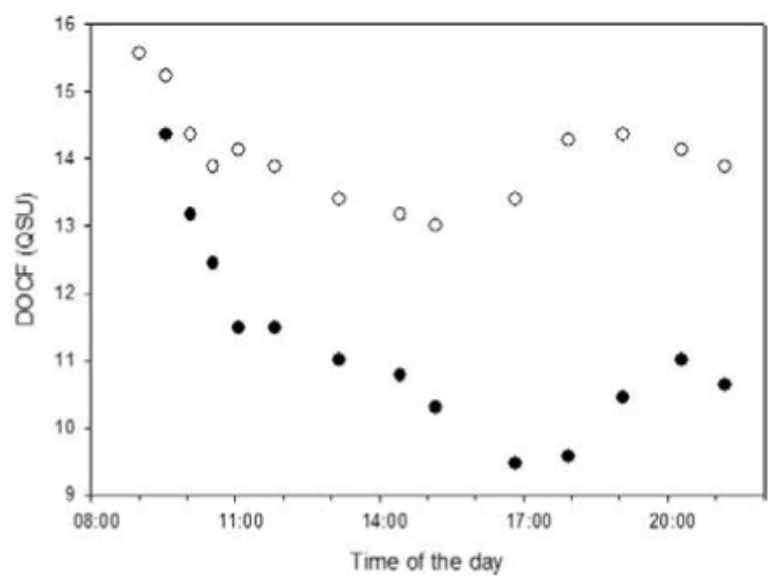

Fig. 9. Diurnal variations in DOCF observed in July 25, 2003, in water from Lake Croche incubated in quartz bottles (solid circles) or not (open circles).

\section{Acknowledgments}

We thank Nicolas Milot, Xavier R. St. Simon, Jerôme Laroulandie, Bouchra Yaakoubd, Justin Shead and Alexandre Poulain for help in the field and laboratory, and Hendrick Van Leeuwen for meteorological data. We also acknowledge funding from the Collaborative Mercury Research Network (COMERN) to M.A.

\section{References}

Allard B. and Arsenie I. (1991) Abiotic reduction of mercury by humicsubstances in aquatic system-An important process for the mer-cury cycle.Water Air Soil Pollut.56,457- 464.

Amyot M., Mierle G., Lean D. R. S., and McQueen D. J. (1994)Sunlight-induced formation of dissolved gaseous mercury in lakewaters.Environ. Sci. Technol.28,2366 -2371.

Amyot M., Mierle G., Lean D., and McQueen D. J. (1997a) Effect ofsolar radiation on the formation of dissolved gaseous mercury intemperate lakes.Geochim. Cosmochim. Acta61,975-987.

Amyot M., Lean D., and Mierle G. (1997b) Photochemical formationof volatile mercury in high Arctic lakes.Environ. Toxicol. Chem.16,2054 2063.

Amyot M., Auclair J. C., and Poissant L. (2001) In situ high temporalresolution analysis of elemental mercury in natural waters.Anal.Chim. Acta447,153-159.

Amyot M., Southworth G., Lindberg S. E., Hintelmann H., LalondeJ. D., Ogrinc N., Kelly C. A., and Poulain A. (2004) Evolution ofdissolved gaseous mercury in large lake enclosures amended with200HgCl2.Atmos. Environ.38,4279 - 4289.

Ben-Bassat D. and Mayer A. M. (1978) Light-induced Hg volatilizationand O2evolution inChlorellaand the effect of DCMU and methylamine.Physiol. Plant.42,33-38.

Bertilsson S. and Tranvik L. J. (2000) Photochemical transformation ofdissolved organic matter in lakes.Limnol. Oceanogr.45,753-762.

Costa M. and Liss P. S. (1999) Photoreduction of mercury in sea waterand its possible implications for Hg0air-sea fluxes.Mar. Chem.68,87-95.

Del Vecchio R. and Blough N. V. (2002) Photobleaching of chro-mophoric dissolved organic matter in natural waters: Kinetics andmodeling.Mar. Chem.78,231-253.

Fitzgerald W. F., Mason R. P., Vandal G. M. and Dulac F. (1994)Air-water cycling of mercury in lakes. InMercury Pollution-Integration and Synthesis(eds. C. J. Watras and J. W. Huckabee),pp. 203-220. Lewis. 
(C) 2005. This manuscript version is made available under the CC-BY-NC-ND 4.0 license http://creativecommons.org/licenses/bync-nd/4.0/ https://www.sciencedirect.com/science/article/pii/S0016703704008531

Garcia E., Poulain A. J., Amyot M., and Ariya P. (2005) Diel variationsin photo-induced oxidation of Hg0in freshwater.Chemosphere,inpress.

Graneli W., Lindell M., and Tranvik L. (1996) Photo-oxidative pro-duction of dissolved inorganic carbon in lakes of different humiccontent.Limnol. Oceanogr.41,698-706.

Kouassi A. M. and Zika R. G. (1990) Light-induced alteration of thephotophysical properties of dissolved organic matter in seawater.Part I. Photoreversible properties of natural water fluorescence.Neth. J. Sea Res.27,25-32.

Lalonde J. D., Amyot M., Kraepiel A. M. L., and Morel F. M. M.(2001) Photooxidation of $\operatorname{Hg}(0)$ in artificial and natural waters.Environ. Sci. Technol.35,1367-1372.

Lalonde J. D., Amyot M., Orvoine J., Morel F. M. M., Auclair J. C., and Ariya P. A. (2004) Photo-induced oxidation of Hg0(aq)in thewaters from the St. Lawrence estuary.Environ. Sci. Technol.38,508 -514

Lanzillotta E., Ceccarini C., Ferrara R., Dini F., and Banchetti R.(2004) Importance of the biogenic organic matter in photo-forma-tion of dissolved gaseous mercury in a culture of the marine diatomChaetocerossp.Sci. Total Environ.318,211-221.

Leifer A. (1988)The Kinetics of Environmental Aquatic Photochem-istry—Theory and Practice.ACS Professional Reference Book.

Lindell M. J., Graneli H. W., and Bertilsson S. (2000) Seasonalphotoreactivity of dissolved organic matter from lakes with con-trasting humic content.Can. J. Fish. Aquat. Sci.57,875-885.

Mason R. P., Lawson N. M., and Sheu G.-R. (1999) Mercury in theAtlantic Ocean: Factors controlling air-sea exchanges of mercuryand its distribution in the upper waters.Deep-Sea Res. II46,937-956.

McKnight D. M., Boyer E. W., Westerhoff P. K., Doran P. T., KulbeT., and Andersen D. T. (2001) Spectrofluorometric characterizationof dissolved organic matter for indication of precursor organicmaterial and aromaticity.Limnol. Oceanogr.46,38 - 48.

Moran M. A., Sheldon M., and Zepp R. G. (2000) Carbon loss andoptical property changes during long-term photochemical and bio-logical degradation of estuarine dissolved organic matter.Limnol.Oceanogr.45,1254-1264.

Nriagu J. O. (1994) Mechanistic steps in the photoreduction of mercuryin natural waters.Sci. Total Environ.154,1-8.

Obernosterer I., Ruardij P., and Herndl G. J. (2001) Spatial and diurnaldynamics of dissolved organic matter (DOM) fluorescence andH2O2and the photochemical oxygen demand of surface waterDOM across the subtropical Atlantic Ocean.Limnol. Oceanogr.46,632-643.

O'Driscoll N. J., Siciliano S. D., and Lean D. R. S. (2003) Continuousanalysis of dissolved gaseous mercury in freshwater lakes.Sci.Total Environ.304,285-294.

O’Driscoll N. J., Lean D. R. S., Loseto L. L., Carignan R., and SicilianoS. D. (2004) The effect of DOC on the photo-production of dissolvedgaseous mercury (DGM) in freshwater lakes: Examining the potentialimpacts of forestry.Environ. Sci. Techonol.38,2664 -2672.

Poulain A. J., Amyot M., Findlay D., Telor S., Barkay T., and Hintel-mann H. (2004) Biological and photochemical production of dis-solved gaseous mercury in a boreal lake.Limnol. Oceanogr.49,2265-2275.

Schindler D. W., Curtis P. J., Bayley S. E., Parker B. R., Beaty K. G.,and Stainton M. P. (1997) Climate-induced changes in the dis-solved organic carbon budgets of boreal lakes.Biogeochemistry36,9-28.

Schroeder W. H., Yarwood G., and Niki H. (1991) Transformationprocesses involving mercury species in the atmosphere-Resultsfrom a literature survey.Water Air Soil Pollut.56,653- 666.

Scully N. M. and Lean D. R. S. (1994) The attenuation of ultravioletradiation in temperate lakes.Arch. Hydrobiol.43,135-144.

Stumm W. and Morgan J. J. (1996)Aquatic Chemistry.Wiley.

Tseng C. M., Lamborg C., Fitzgerald W. F., and Engstron D. (2004)Cycling of dissolved elemental mercury in Arctic Alaskan lakes.Geochim. Cosmoch. Acta68,1173-1184.

Watras C. J., Morrisson K. A., and Host J. S. (1995) Concentration ofmercury species in relationship to other site-specific factors in thesurface waters of Northern Wisconsin lakes.Limnol. Oceanogr.40,556 -565.

Zhang H. and Lindberg S. E. (2002) Trends in dissolved gaseousmercury in the Tahquamenon River watershed and nearshore wa-ters of Whitefish Bay in the Michigan Upper Peninsula.Water AirSoil Poll.133,379-389 